\title{
The impact of new life sciences innovation on political theories of justice
}

\author{
THEO PAPAIOANNOU ${ }^{1}$
}

\begin{abstract}
New life sciences innovation offers the possibility of new conceptions of human nature with significant impact on liberal theories of justice. So far, nature as such has been thought to be something given and beyond human control. Thus, to define something as natural has meant the same thing as to relegate it to the realm of fortune or misfortune, rather than justice or injustice. However, the successful decoding of the human genome and subsequent advances in genomics-based technologies begins to change this conception to a new one: nature can be something dynamic and within human control. Therefore, genomics-based technologies can make possible the just distribution of natural goods (rationality, intelligence, etc). Can liberal political theories successfully deal with this new possibility of justice? This paper addresses the question by briefly assessing Rawls' egalitarianism, Nozick's libertarianism and Sen's capability theory of justice. It is argued that these theories fail to address the new possibility of justice made feasible by life sciences innovation. On the one hand, libertarianism is insensitive to natural inequalities. On the other hand, egalitarianism and the capability theory of justice are limited to compensating for natural inequalities and avoid ensuring just distribution of natural goods. Contemporary liberal theories are not dynamic enough to deal with distributive justice in the 21 st century.
\end{abstract}

\section{Introduction}

New life sciences innovation offers not only the prospect of applications with profound impact on social and economic life but also the possibility of new conceptions of human nature with significant bearing on political theories of justice. So far, nature as such has been theorised as something given and beyond human control (i.e. chance). Therefore, to define something as natural has been to relegate it to the realm of fortune or misfortune (i.e. fate) rather than to the realm of justice or injustice (i.e. responsibility). ${ }^{2}$ Political theories from Hobbes ${ }^{3}$ and Locke ${ }^{4}$ to Rawls ${ }^{5}$ and Nozick ${ }^{6}$ clearly retain this distinction between the two realms. However, the successful decoding of the human genome and subsequent advances in genomicsbased technologies (including biotechnology) create expectations of new diagnostic tools and genetic interventions ${ }^{7}$ which begin to change this static conception of nature to a new one: nature can be something dynamic and within human control (i.e. choice). This implies that nature can be changed to accord with the requirements of justice. To put it another way, genomics-based technologies may make it possible to realise what so far has been thought to be impossible: the just distribution of natural goods such as health, strength, talent, rigour, intelligence, imagination and lifespan. Some of these goods (e.g. intelligence and imagination) are generally assumed to characterise human nature, distinguishing it from animal nature. ${ }^{8}$ The question that arises is: can contemporary liberal theories deal with this new possibility of justice? 
The aim of this paper is to address the question by briefly assessing Rawls' egalitarianism, Nozick's libertarianism and Sen's capability theory of justice. These theories constitute the core of contemporary political liberalism. ${ }^{9}$ However, it will be argued that they fail to address the new possibility of justice put forward by life sciences innovation. On the one hand, resource-based theories such as libertarianism are insensitive to natural inequalities. On the other hand, egalitarianism (also a resource-based theory) and the capability theory of justice are limited to compensating for natural inequalities and avoid ensuring just distribution of natural goods. In some respects this is due to their fixed conception of human nature and their internal contradictions. Contemporary liberal theories are not dynamic enough to deal with distributive justice in the 21 st century.

This paper is structured as follows: firstly we discuss new life sciences innovation and explain how it redefines human nature; secondly, we examine whether contemporary liberal theories can deal with the new possibility of justice; and finally we conclude that neither Rawls' egalitarianism, nor Nozick's libertarianism, nor Sen's capability theory are dynamic enough to address the new possibility of justice in the $21 \mathrm{st}$ century.

\section{New life sciences innovation and the redefinition of human nature}

The term 'new life sciences' marks a shift from $20^{\text {th }}$ century genetics to 21 st century genomics and post-genomics. This shift is characterised by a series of scientific innovations, the most important of which is the successful decoding of the human genome in 2000. The Human Genome Project (HGP) focused on the characterisation and sequencing of the human genome and the relationship between gene activity and cell function. ${ }^{10}$ Since the completion of the HGP and the discovery of, in President Clinton's words, 'nothing less than the language of God', it has been hard to keep up with the pace of innovative developments in new life sciences, let alone their applications to key sectors of the economy and society. Take for instance the health sector. In terms of specific technologies, genomics and post-genomics offer the prospect of development of new gene-based diagnostics and identification of underlying genetic components of diseases. Also the introduction of personalised medicine promises treatments designed for individual patients (i.e. pharmacogenetics) while the development of gene- and cell-based therapies, including gene therapy and the use of stem cells, create expectations not only for preventing and/or curing diseases but also for enhancing human beings. ${ }^{11}$ Genetic enhancements aim at improving fundamental natural goods, including strength, talent, rigour, intelligence and imagination. This would happen by means of new life sciences innovation, especially by manipulating DNA and rewriting genetic codes through somatic cell engineering (SCE) and germ-line engineering (GLE). ${ }^{12}$ These technologies promise alteration of the genes in all cells in the human body. Finally, the development of synthetic biology promises to design and engineer biologically based parts of novel systems as well as redesigning existing natural biological systems. ${ }^{13}$

Scientific and technological innovation has impact on our conceptions of human nature. What is important is the boundary between human control (choice) and what is

Genomics, Society and Policy, Vol.5, No.2 (2009) ISSN: 1746-5354

(C) ESRC Genomics Network. 
beyond human control (chance). As Dworkin recognises, "[t]he whole network of our moral and ethical convictions shifts when technology or discovery makes any dramatic change in the boundary between the two". "Although scientific and technological innovation from the 17th to the 20th centuries had a crucial impact on people's conception of human nature, generally speaking a clear division between chance and choice was maintained. ${ }^{15}$ This resulted in the development of the classical liberal idea of justice that is limited to distribution of social goods such as property, income and wealth. By contrast, natural goods such as intelligence and imagination were thought not to be distributable in terms of justice. Take for instance the 17 th century theorists Hobbes ${ }^{16}$ and Locke ${ }^{17}$. Both promote justice and peace through governmental protection of individual rights to private property but neither emphasises the role of natural goods in civil society. Morally significant goods, say intelligence and imagination, are considered to be fixed properties of human nature and therefore beyond each individual's choice.

It might be argued that $21^{\text {st }}$ century life sciences innovation has the potential to close this division between chance and choice, introducing a new possibility of justice that goes beyond the distribution of social goods. ${ }^{18}$ Indeed, the ability to manipulate DNA and rewrite genetic codes, as well as the possibility of applying engineering principles to design new biological systems (i.e. synthetic biology), have changed static perceptions of nature. Some (morally significant) natural goods and capacities, previously perceived as fixed properties and capacities of human nature, may soon be distributable and therefore a matter of choice. As Jasanoff points out:

The molecularisation of the life sc iences, which enables us both to "read" and manipulate characteristics beneath the visible surfaces of living entities, poses particular challenges to principles of governance based on orderings and classifications ... W e can contemplate altering the hum an genome so as to produce enhanced human beings, with characteristics that today w ould be regarded as out of the ordinary, even superhum an. What then is nature and what is being human? ${ }^{19}$

This crucial question has preoccupied philosophers and political theorists since the beginning of the $21^{\text {st }}$ century. The ability to intervene directly in the human genome and rewrite part of the genome has forced philosophers such as Fukayama ${ }^{20}$ and Kass $^{21}$ to defend the boundary between chance and choice, arguing that new life sciences innovation might endanger human nature. This argument is not only based on the problematic assumption that there are such things as fixed properties of human nature but also on the view that these properties are by definition good. ${ }^{22}$ However, other theorists such as Habermas clearly accept that "...the boundary between the nature that we 'are' and the organic endowments we 'give' to ourselves disappears". ${ }^{2}$ This disappearance provides the basis for redefining or transcending human nature. The latter can no longer be seen as a given entity of fixed characteristics. 
As Buchanan et al point out:

A theory that purports to base justice or morality generally on a fixed human nature canno $t$ tell us wheth er jus tice or morality $p$ ermits or requires us to alter ourselves in fundam ental ways, including ways that change what has been taken to be our nature.

What such a theory can tell us is how to establish the basic structure of society so that we can politically protect the fruits of some natural goods and/or compensate for the absence of some other natural goods. Indeed, this is the case with the classical liberal theory of the 17 th, $18^{\text {th }}$ and 19 th centuries.

Given that the classical liberal theorising of justice has been founded upon assumptions about human nature, any redefinition or transcendence of human nature can gradually begin to develop theoretical presuppositions of a new possibility of justice, i.e. justice that is no longer constrained by human nature.

\section{Contemporary liberalism and the new possibility of justice}

Contemporary liberalism consists of egalitarian, libertarian and capability-based political theories which reconstruct classical liberal arguments of justice. Such reconstructions mainly take place in the 20th century but influence the debate about justice in the 21 st century. Thus, Rawls ${ }^{25}$ develops his egalitarianism upon the social contract tradition of Rousseau and Kant while Nozick ${ }^{26}$ reconstructs Locke's libertarianism and Sen ${ }^{27}$ critically modifies the liberal arguments of Smith, Condorcet and J. S. Mill. Although contemporary liberal thinkers do not seem to be explicitly preoccupied with the new possibility of justice, it might be useful to explore whether their arguments implicitly preclude their extension or revision to genomics or preclude their use in building new theoretical frameworks which extend to genomicsrelated questions.

Rawls

To begin with Rawls, his starting point is that the natural lottery is no less morally arbitrary than the social lottery. According to him, "No one is thought to deserve his greater natural capacity or to merit a more favourable starting place in society". ${ }^{28}$ However, the moral arbitrariness of the natural lottery does not seem to justify direct intervention in the human genome for equalising natural capacity. Despite opposing interpretations ${ }^{29}$, Rawls is clear that although no one deserves his greater natural capacity, morally arbitrary distinctions which are due to the natural lottery should not be eliminated or scaled down. In his theory, there is another way to deal with them: the basic structure of society can be arranged so that these morally arbitrary distinctions can work to everyone's advantage. Rawls is convinced that the system can be justified to all and therefore to the least favoured 'representative man'. This arrangement can be achieved through two principles of justice: the equal liberty and the difference principles.

Both principles apply to major social institutions and require specifications of the notions of advantage and benefit, assigning weights to certain primary goods. Rawls

Genomics, Society and Policy, Vol.5, No.2 (2009) ISSN: 1746-5354

(C) ESRC Genomics Network. 
defines primary goods as "...things which rational persons may be presumed to want whatever else they want". ${ }^{30}$ However, as Farrelly correctly observes:

Rawls divides these goods into two groups - social and natural primary goods:

Social Prim ary Goods (SPG): rights and liberties, powers and opportunities, income and wealth, and self-respect.

Natural Prim ary Goods (NPG): hea lth and vigour, intelligence and imagination.

Indeed, Rawls' theory of justice claims that only the SPG can be equally distributed unless unequal distribution of them is to everyone's advantage. Thus, Farrelly correctly raises the issue: "But what about the NPG? Why does Rawls not include the distribution of them in the principles of justice?" ${ }^{32}$ First, it might be argued that the non-inclusion of the distribution of NPG in the principles of justice does not imply that Rawls regards natural inequalities as falling outside the domain of justice. As Buchanan et al stress: "Rawls' remarks about the moral arbitrariness of natural inequalities ...mean that in some sense he regards natural inequalities as falling within the domain of justice." 33 Second, even if this is the case, Rawls claims that NPG are not directly under the control of the basic structure of society. This claim is due to his classical liberal conception of human nature that constrains a new possibility of Rawlsian justice. As Rawls confesses "...the feasible ideals of the person are limited by the capacities of human nature and the requirements of social life". ${ }^{34}$ Rawls does not consider how innovation redefines conceptions of human nature and revolutionises debates concerning social justice. That is not to say his theory is completely irrelevant (it would be unfair and anachronistic if we so argued, since his A Theory of Justice was written in 1971) but it is an ideal theory that does not pay much attention to 'real issues' in politics such as the role of technological innovation. Rawls' idealism has been already criticised by several political theorists, including Barry, ${ }^{35}$ Farrelly ${ }^{36}$ and Mason. ${ }^{37}$

However, his neglect of innovation is particularly important because it minimises the relevance of his theory for modern life institutions. As Buchanan and Keohane argue, given the crucial role of innovation in modern life, theorising about social justice should not ignore the potential of innovations to ameliorate injustices. ${ }^{38}$ This is the reason why followers of Rawls such as Farrelly attempt to extend Rawls' theory to address issues raised by new life sciences innovation. Farrelly proposes a revised theory of justice that incorporates Rawlsian principles to govern the distribution of NPG. His starting point is that: "It is no longer viable to invoke the standards of social justice from a world where it was only the SPG that were directly under the control of the basic structure." ${ }^{39}$ Farrelly is convinced that the future society will be one where the distribution of NPG will be under the control of the basic structure. This raises the question of the principles which should govern the distribution of NPG. 
As an answer, Farrelly proposes a 'genetic difference principle' (GDP).

This princ iple states: GDP: inequal ities in the distribution of genes important to the NPG are to be arra nged so that they are to be the greatest benefit of the least advantaged.

Farrelly argues that this principle does not invoke the old standards of traditional property and privacy rights. However, it is not clear whether GDP complements these standards or applies to the basic structure of society as an entirely new principle. According to Farrelly: "The rights to property and privacy are given a priority in Rawlsian justice because they are crucial for allowing people to pursue their rational plans of life. But are they more important than one's natural endowments?"41

Farrelly's answer is negative because he takes private ownership of information in the human genome to mean that the NPG of the rich are going to be cared for, while the NPG of the poor are going to be neglected. It might be said that even if rights to property and privacy are no longer a priority, the application of GDP to the basic structure of society does not imply that the NPG of the poor are going to be cared for. There is an epistemological problem of defining the least advantaged in terms of NPG. Who are the least advantaged?

This question is also raised by some prioritarians who investigate which individuals qualify as members of the worst-off group of society. For instance, Lindsay ${ }^{42}$ insists that severely cognitively impaired individuals qualify as members of the least advantaged group and for this reason they deserve massive transfer of socio-economic resources from the rest of society. However, it is not clear why this genetically disadvantaged group should be given priority over other genetically disadvantaged groups. Nor is it clear why victims of genetic diseases should be given priority over victims of socio-economic circumstances (e.g. those born in poverty). Farrelly's reply to prioritarians such as Lindsay is that the interests of different disadvantaged groups need to be balanced one against another. The GDP does not trump those principles that govern the distribution of SPG. In addition, society should decisively deal with the issue of "which genetically disadvantaged group should be given priority over other genetically disadvantaged groups". "Farrelly's reply fails to address the epistemological problem that is at the heart of prioritarian investigations: how can we define the least advantaged in terms of NPG?

Even if we could provide a plausible definition of the least advantaged in terms of NPG, one question would still remain open: what does it mean to talk about the distribution of NPG being brought 'under the control of the basic structure of society'? Farrelly's GDP clearly permits inequalities in NPG to benefit the least well off but only by increasing the level of SPG. Farrelly is well aware of this problem but provides no solution. Instead he defends the reconciliation of "the principles governing the distribution of the SPG with those governing the distribution of the NPG" ${ }^{44}$ Unfortunately, Farrelly is not clear about how this can happen. It might be said that only an abstracted difference principle can be applied to both SPG and NPG. This presupposes SPG and NPG are understood as interpersonal and interdependent goods of equal importance to pursuing a rational plan of life.

Genomics, Society and Policy, Vol.5, No.2 (2009) ISSN: 1746-5354

(C) ESRC Genomics Network. 


\section{Nozick}

Nozick's starting point is opposite to that of Rawls: neither the natural lottery nor the social lottery is morally arbitrary. The reason for this is that: "Individuals have rights, and there are things no person or group may do to them (without violating their rights)" ${ }^{45}$ In Nozick's theory, the most important inviolable right is that of selfownership:

Every person is morally entitled to full private property in his person and powers. This $\mathrm{m}$ eans that each person has an extensive set of moral rights...over the use and fruits of his body and capacities...

The right to self-ownership implies that, even if the natural lottery is morally arbitrary, people are entitled to their natural goods and what flows from them. This entitlement is founded upon Nozick's three principles of justice: acquisition, transfer and rectification. ${ }^{47}$

These principles require that neither natural goods, such as intelligence and imagination, nor social goods, such as income and wealth, that flow from natural goods can be centrally distributed by means of life sciences innovation. Since individuals are self-owners, they are morally justified to do with their natural goods whatever they wish, provided they do not harm the non-consenting others. This implies that they are free to alter their own genetic profile or choose particular natural goods. Although Nozick reconstructs Lockean libertarianism, he does not have a fixed conception of human nature that prevents him from considering the role of science in debates of distributive justice. Thus, he defends positive genetic engineering as a means by which prospective parents might be able to choose genetic profiles for their children. According to Nozick:

[M] any biologists tend to think th e problem is one of design, of specifying the best types of persons so that biologists can proceed to produce them... They do not tend to think ... of a syste $\mathrm{m}$ in which they run a "genetic superm arket" $m$ eeting the individual specifications (within certain moral lim its) of pr ospective parents... This superm arket system has the great virtue that it involves no centralised decision fixing the future of human type(s). ${ }^{48}$

The idea of allowing parents to alter or choose the genetic profile of their children is directed against any political state more extensive than the minimal state that might use life science innovation for creating certain types of people, maximising aggregate utility and welfare. This would violate the Kantian imperative that requires people to be treated as ends and not simply as means. However, the same idea might also result in some problematic parental choices. For instance, Glover asks us to "[i]magine parents belonging to some extreme religious sect, who wanted their children to have a religious symbol as a physical mark on their face, and who wanted them unable to read, as a protection against their faith being corrupted". ${ }^{49}$ In this scenario children are treated as simply a means for the satisfaction of their parents' wishes. 
Nevertheless, neo-libertarians such as Savulescu reply that, in fact, "It is unlikely that any parent ever desires a child solely as an end in itself..." door to violations of child's self-ownership for the sake of parents' procreative autonomy. ${ }^{51}$ According to Savulescu:

Procreative autonomy is the liberty to decide when and how to have children according to $\mathrm{w}$ hat parents judge is best. Parents know best their own circum stances, and ultim ately it is parents who must live with and make sacrifices for their children. ${ }^{52}$

The libertarian principle of procreative autonomy can lead to problematic parental choices simply because it allows parents to decide, according to their conception of the good, what is the best life for a child. Problematic parental choices might limit the child's opportunities to lead an autonomous and meaningful life. In other words, as Habermas puts it, such choices might "carry the risk of harming the sense of individual autonomy as well as the moral status of persons so treated". ${ }^{53}$ Habermas' critique of 'genetic libertarianism' is important and raises crucial questions: How is one's genome selected? According to whose conception of the good is one's genome selected? Answering these questions might indeed have implications for one's personhood so far as autonomy is concerned. One might think oneself less free than others, given that one might not have the means to alter one's pre-selected genome according to one's own conception of the good. This is incompatible with libertarianism as such. Therefore, it might be said that contemporary libertarianism, even though implicitly accepting the new possibility of justice, is limited by its internal contradictions.

Sen

In the Tanner Lectures on Human Values (1980), Sen asserts that what matters in the discussion of social justice is not the question 'why equality' but the question 'equality of what?' ${ }^{54}$ Although Rawls equalises SPG and Nozick equalises individual rights, Sen insists that what should be equalised is capability. In this sense, his theory of justice shifts focus from institutional structures to freedoms of people. Institutional structures only govern the means to freedom but do not provide freedom itself. Sen is critical of Rawlsian and Nozickian principles of justice because they become central issues in judging distributional equity. In his view, resources are merely the means to freedom for people to choose different kinds of life. As Sen explains:

Justice cannot be indifferent to the lives that people can actually live. The importance of hum an lives, expe riences and realisations cannot be supplanted by inform ation about institutions that exist and the rules that o perate ... We have re ason to be inte rested ... in th $\mathrm{e}$ freedoms that we actually have to choose between different kinds of lives.

This is what the notion of capability refers to: each individual's actual freedom to achieve the functioning he/she values (leading an autonomous and meaningful life). Sen arrives at the notion of capability through his critical assessment of Rawlsian

Genomics, Society and Policy, Vol.5, No.2 (2009) ISSN: 1746-5354

(C) ESRC Genomics Network. 
primary goods and the concept of utility or welfare. As Cohen points out: "Sen pleaded for a metric of well-being which measured something between primary goods and utility." 56 Indeed, Sen's dissatisfaction with Rawlsian primary goods is founded on the notion that that some individuals are incapable of converting them into wellbeing or welfare because of the variation in their natural characteristics. To put it another way, differences in NPG are sometimes determinants of the incapability of individuals to convert SPG into valuable functions. As Daniels observes, this criticism derives from Arrow, "who noted that people who were ill or disabled might be worse off than others despite enjoying the same index of primary social goods". 57 Similarly, people who were less talented or less intelligent than others might be worse off, despite enjoying the same index of social primary goods. Here the problem is bridging the gulf between SPG and NPG that Rawls' theory leaves unresolved. As has been argued, his difference principle only mitigates the effects on those with the worst NPG while the GDP posited by his followers (eg Farrelly) remains problematic. The question that arises is whether Sen's capability theory of justice can bridge the gulf between SPG and NPG, going beyond Rawls to convert them into well-being.

To be sure, variability in NPG is a source of inequality in capabilities and for this reason it requires adjustment. But what sort of adjustment? Is it just a simple adjustment of social and economic resources that can mitigate the effects of this inequality by compensating variability in NPG? Is it an adjustment of genetic resources (through the use of new life sciences technologies) that can eliminate the effects of inequality in capabilities by reducing variability in NPG? Or is it a complex and co-ordinated adjustment both of socio-economic and genetic resources that can first compensate for and then eliminate the effects of inequality in capabilities? It might be argued that Sen, despite the fact that he assesses well-being in terms of capability, fails to provide clear answers to these questions. This implies that his theory may be not very far from that of Rawls on the issue of NPG. To put it another way, Sen's theory seems to be limited to the mitigation of effects of variability of NPG by means of adjusting socio-economic resources. Although the capability theory, by comparing freedoms (different functionings) instead of social primary goods and utility, appears to be more appropriate than Rawlsian egalitarianism to indicate where the injustices between people lie, it seems to be inappropriate (just like the Rawlsian egalitarianism) to eliminate them when adjustment of NPG is required.

Sen concludes that:

We are diverse, but we are divers e in different ways. One variation relates to the differences that exist among our ends and objectives ... But there is another im portant diversity - variations in our a bility to convert resources into actual freed oms. Variations related to sex, age, genetic endowm ents, and $\mathrm{m}$ any other features give us unequal powers to build freedom in our liv es even when we have the sam e bundle of primary goods. ${ }^{58}$

What Sen is not clear about is whether, in equalising powers to build freedom in our lives, we are justified in using new life sciences technologies to reduce some

Genomics, Society and Policy, Vol.5, No.2 (2009) ISSN: 1746-5354

(C) ESRC Genomics Network. 
variations related to genetic endowments. In fact, he leaves this particular question open. This incomplete account is the weakness but also the strength of Sen's approach because it keeps it open to interpretation, avoiding perfectionism and paternalism. Thus, it is up to Sen's followers to resolve the issue of extension of the capability approach to genomics. Some of his followers, such as Cooke ${ }^{59}$, suggest that his theory does not preclude its extension to genomics. On the contrary, they argue, if Sen's argument for the moral obligation to redistribute resources towards capabilities is right, then a similar argument can be made about a moral obligation to use life sciences innovation to genetically engineer individuals who would otherwise not live up to the threshold of their capabilities due to a preventable lack of certain NPG. Cooke, in particular, uses the example of GLE technologies to argue that liberal societies should alter germ-line to ensure basic level capabilities. ${ }^{60}$ Unfortunately, she overlooks that Sen's theory is open-ended and does not support complete capability equality.

However, some other followers of Sen, such as Nussbaum, ${ }^{61}$ are not open to new life sciences innovation. Rather, they explicitly argue that natural determinants of capabilities cannot be controlled through the use of new technologies. Thus, especially for Nussbaum, "it is still the social basis of the good, not the good itself that society can reliably provide". ${ }^{62}$ This argument clearly fails to take Sen's capability approach beyond Rawls' theory, dealing with the new possibility of justice. More importantly, it seems to contradict Nussbaum's idea of human dignity. She writes:

The core id ea is that of the hum an being as a dignified free being who shapes his or her own life in cooperation and reciprocity with others, rather than being passively shaped or pushed around by the world in the manner of "flock" or "h erd" animal. A life that is really human is one that is shaped throughout by hum an powers of practical reason and sociability. ${ }^{63}$

Nussbaum's idea of human dignity is founded upon the Marxist conception of human life as a continuous process of emancipation. Thus it cannot justify a static situation in which human beings are passively shaped or pushed around by either nature or society. In this sense, human dignity seems to justify the use of new life science technologies for controlling the natural determinants of human capabilities. Whether this approach is a plausible alternative to contemporary liberal theories is an open question. What is certain is that it is a less narrow approach to genomics and postgenomics questions of distributive justice than that of contemporary liberalism.

\section{Conclusion}

This paper has sought to address the question of whether contemporary liberal theories can successfully deal with the new possibility of justice, namely, just distribution of natural goods such as intelligence and imagination, or whether the theories are precluded from being extended or revised to take account of new life sciences innovation. Three such theories have been examined: Rawls' egalitarianism, Nozick's libertarianism and Sen's capability theory of justice. 
It might be concluded that, despite their differences, none of them is clearly able to address the issues that the new possibility of justice raises in the 21 st century. Rather, contemporary liberal theories fail to lead us to ponder the right ethico-political questions in the genomics and post-genomics era (e.g. who are the least advantaged? How do we balance the duties to mitigate both the social and natural lotteries?). ${ }^{64}$ First, Rawls' liberalism equalises SPG and compensates for the worst NPG so that they are to the greatest benefit of the least advantaged. Although Farrelly clearly recognises the need for incorporation of Rawlsian principles to govern the distribution of NPG, he provides an incomplete and problematic account of egalitarian liberal genetic justice. Second, libertarianism, represented by Nozick and his followers, applies the old standards of property and privacy rights to govern the distribution of NPG. This application undermines the very essence of libertarianism, namely the autonomy of each individual and his/her ability to lead a meaningful life. Third, Sen's capability theory, even though it recognises that variability in NPG is a source of inequality in human capabilities, fails to specify adjustments which can eliminate this inequality. Given the open-ended character of his theory, some followers of Sen (e.g. Cooke) argue for genetic interventions to ensure basic level of capabilities, while others (e.g. Nussbaum) insist that genetic determinants of capabilities cannot be socially controlled. However, there seems to be an alternative approach to genomic and post-genomic questions of distributive justice. That is the approach of human dignity, and it should be investigated for its plausibility.

The inability of contemporary liberal theories to deal with the new problem of justice is a result of their failure to consider the impact of new life sciences innovation on the relationship between chance and choice. This failure is partly explained by the fact that they reconstruct classical liberal arguments founded upon fixed conceptions of human nature. Another explanation is that the science is not yet settled and therefore contemporary liberal theories cannot possibly come up with concrete conclusions. However, if one accepts that the acceleration of new life sciences innovation increases choice and decreases chance, one has also to accept the need for less narrow theories of justice which are able to capture this change by extending/revising to genomic and post-genomic questions of distributive justice. The task of these theories will be not simply to incorporate NPG into their arguments, but to do so in a way that will avoid genetic essentialism, i.e. emphasis on genetic factors rather than social practices. If the aim of justice is to extinguish both the influence of arbitrary socio-economic factors and brute luck on distribution, then a combination of both SPG and NPG must be incorporated into new arguments about justice.

\footnotetext{
${ }^{1}$ ESRC Innogen Centre and Development Policy and Practice, The Open University, Milton Keynes, UK t.papaioannou@open.ac.uk

${ }^{2}$ A. Buchanan et al. 2000. From Chance to Choice: Genetics and Justice. Cambridge: Cambridge University Press.

${ }^{3}$ T. Hobbes. 1651. Leviathan. R. Tuck, ed. 1991. Cambridge. Cambridge University Press.

${ }^{4}$ J. Locke. 1689. Two Treatises of Government. P. Laslett, ed. 1988. Cambridge: Cambridge University Press.

${ }^{5}$ J. Rawls. 1972. A Theory of Justice. Oxford. Oxford. University Press.
}

Genomics, Society and Policy, Vol.5, No.2 (2009) ISSN: 1746-5354

(C) ESRC Genomics Network. 
${ }^{6}$ R. Nozick. 1974. Anarchy, State, and Utopia. Oxford. Blackwell.

${ }^{7}$ T. Propp and H. M. Moors. Will Genomics Erode Public Health and Prevention? A Scenario of Unintended Consequences in the Netherlands. Science and Public Policy 2009; 36(3): 199-213.

${ }^{8} \mathrm{We}$ acknowledge that the notion of human nature also includes some other core capacities such as reason and sociability. However, a different analysis would be needed to establish precisely how new life sciences innovation might impact on these capacities. It is unlikely that most genetic interventions would be focused on changing levels of reason and sociability; they would most likely be aimed at such fundamental natural goods as intelligence and imagination, provided that safety concerns are addressed (see J. R. Loftis. Germ-line Enhancement of Humans and Nonhumans. Kennedy Institute of Ethics Journal 2005; 15(1): 57-76).

${ }^{9}$ Despite their differences, these theories can be broadly classified as liberal theories of justice because of the importance they place on individual freedom.

${ }^{10}$ H. Gottweis. The Governance of Genomics. Critical Public Health 2002; 12 (3): 207-220.

${ }^{11}$ E. Fenton. Genetic Enhancement: A Threat to Human Rights? Bioethics 2008; 22(1): 1-7.

${ }^{12}$ Somatic cells are mainly skin or muscle cells, they contain 23 chromosomal pairs and do not transmit genetic information to future generations. By contrast, germ-line cells are the egg and sperm cells, they contain 23 chromosomes and transmit genetic information to offspring as well as to future generations (see F. Allhoff. Germ-line Genetic Enhancement and Rawlsian Primary Goods. Kennedy Institute of Ethics Journal 2005; 15(1): 39-56).

${ }^{13}$ The Royal Academy of Engineering. 2009. Synthetic Biology: Scope, Applications and Implications, www.raeng.org.uk/news/publications/list/reports/Synthetic biology.pdf [Accessed 4 March 2010]

${ }^{14}$ R. Dworkin. 2000. Sovereign Virtue: the Theory and Practice of Equality. Cambridge Massachusetts. Harvard University Press: 287.

${ }^{15}$ It should be noted that the eugenics movements of 1870-1950 constitute a particular exception to this general rule. Eugenics rejected any clear division between chance and choice on the grounds of this (problematic and unfounded) belief; that the source of social problems is in the genes of individuals and therefore, by altering the pattern through which these genes are transmitted to future generations, the social problem would be automatically resolved. As Buchanan et al (2000. From Chance to Choice: Genetics and Justice. Cambridge: Cambridge University Press: 28) remind us, "the history of eugenics is not a proud one. It is largely remembered for its shoddy science, the blatant race and class biases of many of its leading advocates and its cruel program of segregation, and later, sterilisation of hundreds of thousands of vulnerable people who were judged to have substandard genes. Even worse, eugenics, in the form of 'racial hygiene', formed part of the core of Nazi doctrine".

${ }^{16}$ Hobbes, op. cit. note 3.

${ }^{17}$ Locke, op. cit. note 4.

${ }^{18}$ This, in fact, sketches a move from 'fate' to 'responsibility' i.e. responsibility for just distribution of natural goods.

${ }^{19}$ S. Jasanoff. 2005. Designs on Nature: Science and Democracy in Europe and the United States. Princeton and Oxford. Princeton University Press: 26.

${ }^{20}$ F. Fukayama. 2002. Our Post-Human Future: Consequences of the Biotechnology Revolution. New York. Ferrar, Straus \& Giroux.

${ }^{21}$ L. Kass. 2000. The Wisdom of Repugnance. In The Human Cloning Debate. G. McGee, ed. $2^{\text {nd }}$ ed. Berkeley, CA. Berkeley Hills Books.

${ }^{22}$ J. Glover. 2006a. Choosing Children: the Ethical Dilemmas of Genetic Intervention. Oxford. Oxford University Press.

${ }^{23}$ J. Habermas. 2003. The Future of Human Nature. Cambridge. Polity Press: 12.

${ }^{24}$ Buchanan et al, op. cit. note 2, p.92.

${ }^{25}$ Rawls, op. cit. note 5.

${ }^{26}$ Nozick, op. cit. note 6.

${ }^{27}$ A. K. Sen. 1980. Equality of What? In Tanner Lectures on Human Values. S. McMurrin ed. Cambridge. Cambridge University Press.

${ }^{28}$ Rawls, op. cit. note 5, p.165. 
${ }^{29}$ G. Pence. 2000. Recreating Medicine: Ethical Issues at the Frontiers of Medicine. New York. Rownman and Littlefield Publishers; E. Cooke. Germ-line Engineering, Freedom, and Future Generations. Bioethics 2003; 17(1): 32-58.

${ }^{30}$ Rawls, op. cit. note 5, p. 158 .

${ }^{31}$ C. Farrelly. Justice in the Genetically Transformed Society. Kennedy Institute of Ethics Journal 2005; 15(1): 78 .

${ }^{32}$ Ibid

${ }^{33}$ Buchanan et al, op. cit. note 2, p.68

${ }^{34}$ Rawls, op. cit. note 5, p.321.

${ }^{35}$ B. Barry. 2005. Why Social Justice Matters? Cambridge and Malden MA. Polity. ${ }^{36}$ Farrelly, op. cit. note 31 .

${ }^{37}$ A. Mason. Just Constraints. British Journal of Political Science 2004; 34: 251-268.

${ }^{38}$ A. Buchanan and R. O. Keohane. Justice in the Diffusion of Innovation. 2009. http://depts.washington.edu/uwch/docs/GJConf08-09Buchanan\%20pap\%20INNJUS1\%204\%20final\%2003\%2025\%2009.pdf [Accessed 4.March 2010]

${ }^{39}$ Farrelly, op. cit. note 31, p.78.

${ }^{40}$ Farrelly, op. cit. note 31, p.81.

${ }^{41}$ Farrelly, op. cit. note 31, p.79.

${ }^{42}$ R. Lindsay. Enhancements and Justice: Problems in Determining the Requirements of Justice in a Genetically Transformed Society Kennedy Institute of Ethics Journal 2005; 15(1): 3-38.

${ }^{43}$ Farrelly, op. cit. note 31, p.94.

${ }^{44}$ Farrelly, op. cit. note 31, p.82.

${ }^{45}$ Nozick, op. cit. note 6, p. ix.

${ }^{46}$ G. A. Cohen and K. Graham. Self-Ownership, Communism and Equality. Proceedings of the Aristotelian Society 1990; 64: 25.

${ }^{47}$ Nozick, op. cit. note 6, p.226.

${ }^{48}$ Nozick, op. cit. note 6, p.315.

49 J. Glover. 2006b. Questions about Some Uses of Genetic Engineering. In Bioethics: An Anthology.

H. Kuhse and P. Singer eds. $2^{\text {nd }}$ Ed. Oxford. Blackwell Publishing:194.

${ }^{50}$ J. Savulescu. 2006. Sex Selection: The Case For. In Bioethics: An Anthology. H. Kuhse and P. Singer eds. $2^{\text {nd }}$ Ed. Oxford. Blackwell Publishing: 147.

${ }^{51}$ Of course one might argue that the potential for parents to treat children solely as a means and not also as ends in themselves is problematic for libertarianism generally and not only in the particular context of Savulescu's argument.

${ }^{52}$ Savulescu, op. cit. note 50, p.148.

${ }^{53}$ Habermas, op. cit. note 23, p.96.

${ }^{54}$ Sen, op. cit. note 27.

${ }^{55}$ A. Sen. 2009. The idea of Justice. London. Penguin:18.

${ }^{56}$ G. A. Cohen. On the Currency of Egalitarian Justice. Ethics 1989; 99(4): 942.

${ }^{57}$ N. Daniels. Equality of What? Welfare, Resources, or Capabilities? Philosophy and Phenomenological Research 1990: 50 (Supplement): 276.

${ }^{58}$ A. Sen. Justice: Means versus Freedoms. Philosophy and Public Affairs 1990; 19(2): 120-121.

${ }^{59}$ Cooke, op. cit. note 29.

${ }^{60}$ Ibid

${ }^{61}$ M. C. Nussbaum. 2000. Women and Human Development: The Capabilities Approach. Cambridge. Cambridge University Press.

${ }^{62}$ Nussbaum, op. cit. note 60, p. 81 .

${ }^{63}$ Nussbaum, op. cit. note 60, p. 72 .

${ }^{64}$ This important point was made by one of the GSP referees. I would like to thank him/her for the contribution. 